\title{
Day Surgery Development Aspects in Slovakia
}

\section{Beáta GaVurová a , Adela KlePÁKová ${ }^{\mathbf{b}}$, LAdislava IVANČová ${ }^{\mathrm{c}}$}

a Technical University in Košice, Faculty of Economics, Němcovej 32, 04001 Košice, Slovakia. Email: beata.gavurova@tuke.sk

${ }^{b}$ University of P.J. Šafárik in Košice, Faculty of Public Administration, Popradská 66, 04011 Košice, Slovakia.E-mail: aklepakova@gmail.com

${ }^{c}$ University of Economics in Bratislava, Faculty of Applied Languages, Dolnozemská cesta, 85235 Bratislava,Slovakia.E-mail: ladislava.ivancova@euba.sk

\begin{abstract}
The day surgery is a highly effective tool for providing health care which has been used in Slovakia only for the last decade. The unified system of payment for inpatient or outpatient (day care) surgeries causes the reduction of health insurance companies' spending. Incorrectly configured and economically demotivating system of refunding is a cause of lagging behind the European average in utilization of day surgery. Without the evaluation of day surgery it is not possible to link the progress in the social sphere, which leads to the restriction of day surgery availability for some social groups and thus the subsequent stagnation of day surgery in Slovakia. This contribution presents a pilot study conducted in Slovakia and its partial findings focused on the development and trends in the implementation of day surgery in order to increase the efficiency healthcare system.
\end{abstract}

Keywords: Day Surgery, Healthcare, Health Care Development.

\section{Aspectos del desarrollo potencial de cirugía ambulatoria en Eslovaquia}

\section{RESUMEN}

La cirugía ambulatoria (CA) constituye una herramienta altamente eficaz en la prestación de asistencia sanitaria que en Eslovaquia se está utilizando sólo durante la última década. El sistema de pago único por actos de cirugía ambulatoria y normal es motivo de reducción de gastos de la seguridad médica. El sistema de pagos incorrectamente ajustado y económicamente desmotivador causa atraso en el aprovechamiento de la CA en comparación con la media europea. Sin evaluar la CA resulta imposible interrelacionar el avance de la misma con la esfera social, por lo cual se produce la limitación de su accesibilidad para ciertas capas sociales y, por consiguiente, su estancamiento en Eslovaquia. Este artículo presenta el estudio piloto realizado en Eslovaquia y sus resultados parciales enfocados al desarrollo y tendencias de implementación de la CA con el fin de aumentar la eficacia del sistema sanitario.

Palabras Clave: Cirugía ambulatoria, sanidad, desarrollo de asistencia sanitaria.

JEL Classification: I13, I14, I15, I18

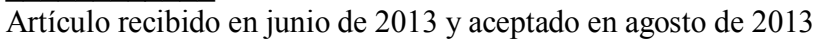

Artículo disponible en versión electrónica en la página www.revista-eea.net, ref. ə-31213 


\section{INTRODUCTION}

The hospital sector remains the largest single component of health spending in OECD and EU countries, accounting for around one third of total health expenditure. The progress in the development of less invasive surgical interventions and better anesthetics have enabled shorter lengths of stay in hospitals and the expansion of same-day surgery in hospitals or in other health care facilities (Lafortune et al., 2012). Besides from the extraordinary cases, the day surgery is advantageous for patients and their families, but also for health care providers, health insurers and health system regulator. There are significant differences in the development and use of day surgery among the countries arising from varying legislative incentives and regulations, financial reimbursement paid for day surgery, as well as the approaches of doctors and anesthesiologists (Aylin at al, 2005; Koechlin et al., 2010). Continuous improvement in surgical and anesthetic techniques are conditioned by further development of procedures suitable for day surgery, and this trend is particularly evident in the expansion of laparoscopic and minimum invasive surgery.

Following the results of numerous studies carried out abroad we can conclude that day surgery is expanding constantly, both in the number of operated patients, as well as in larger and more complex application of surgeries for patients with higher comorbidity (Martinussen and Hagen, 2009; Martinussen and Midttun, 2004). Day surgery covers a wide spectrum of surgical procedures, embracing all surgical specialties, from operations under local anesthesia to major ones under general anesthesia. Many procedures of medical services enable releasing patients from hospital to home care in the day of surgery. Other treatments require overnight stay in hospital or a short stay in hospital within 72 hours.

Despite the above mentioned, day surgery in Slovakia is characterized by a small number of workplaces designed for day health care. Also, it has a discouraging funding system of day surgery performances paid to health care providers. The population still prefers hospitalization prior to day surgery. Slovakia lacks in stronger legislative support, coordinated approach of day surgery actors, communication between health care providers, health insurers and patients, and follow-up home care or nursing care. For more than ten years of providing day surgery in Slovakia, there has not yet been realized and published any complex research study dealing with day surgery and its aspects. There is an absence of broader information for potential patients about the nature, conditions and other selected attributes of day surgery. This should be provided from the health insurance companies or individual health care providers, or from healthcare system regulatory body itself. Funding system of hospital facilities is suppressing the motivation of hospitals to move patients into a day surgery. It declares a very low use of day surgery, not reaching the level of $10 \%$ of the 
total surgeries performed. The neighboring Czech Republic achieves four times higher share of day surgery operations out of all operations performed. Developed countries of Europe and the U.S. exceed this share by nine times (Hudecová, 2010). Slovak republic has not participated in collecting surgical data for OECD or Eurostat statistics yet; therefore it has not been possible to compare the results with other EU countries.

The goal of the research is to map the current condition of day surgery data collecting in Slovakia. This contribution reflects partial results of the historically first extensive pilot research study conducted in Slovakia. It emphasizes the negative findings which hinder the development of day surgery in Slovakia.

\section{CURRENT STATE OF THE PROBLEM}

The Organization of Economic Cooperation and Development (OECD), European Statistics (Eurostat) and World Health Organization (WHO) in Europe have been collecting data on surgical procedures as part of their broader data collection on health care statistics since 1960. The three organizations are planning to integrate the data collection on this topic into the OECD/Eurostat/WHOEurope joint questionnaire in 2013. Collecting data on surgical procedures at the international level is challenging and difficult for three main reasons (Lafortune et al., 2012):

1. Lack of unified international classification of procedures.

2. Differences in the methods of correct procedures reporting.

3. Problems with data reporting of the day surgeries provided.

In general, we can specify striking disparities in the rate of published surgical performances in particular European countries; those could be classified into the areas as seen in the Figure 1.

Research studies declare also significant changes in realized health care performances (procedures) as an important determinant influencing the rate of reported realized surgical performances. This means that changes in demand for the given type of surgical performances are not as important as the differences in medical practice linked together with factors on the side of supply. In medical practice are declared disparities not only between countries, but also in the frame of each country (ex. Dartmouth Atlas of Health Care, 2012; NHS, 2011). They correlate also with the riskiness of the given type of performances for particular group of patients, or also with medical recommendation for the given type of performances for patients with exactly specified conditions (Lafortune et al., 2012). This only multiplies the importance and difficulties of solving the questions of efficiency and equality in the area of health care services providing. 
Figure 1

Determinants and ties in process of surgical performances reporting

\begin{tabular}{|l|l|l||}
\hline $\begin{array}{l}\text { Problematic data comparison: } \\
\text { Problematic data collection about } \\
\text { surgical performances. } \\
\text { Differences in surgical performances. }\end{array}$ \\
\hline $\begin{array}{l}\text { Disparities among the countries and inside } \\
\text { of each country. }\end{array}$ \\
OPESTION OF EFFECTIVITY AND EQUALITY \\
IN THE HEALTHCARE SYSTEM
\end{tabular}

Source: Own elaboration.

A comparison of the OECD, Eurostat and WHO-Europe data collection on the aggregate number of surgical procedures reported wide inconsistencies in national data submissions to the three international organizations (Table 1).

Recognizing the difficulties in promoting consistent data reporting across countries in the absence of international classification procedures, the three organizations decided to discontinue their data collection on the aggregate number of (surgical) procedures and to focus their work on improving the data collection. A proper monitoring of the development of day surgery in different countries should be based, ideally, on a full coverage of activities in hospitals and in other settings (e.g., in clinics or specialized ambulatory surgery centers). The OECD and Eurostat data collections have traditionally included a breakdown between in-patient cases and day cases, with day cases usually defined as patients admitted to the hospital and discharged the same day. As to the day surgery activities, such data collection did not explicitly cover all the day surgeries that may have been carried out as outpatient cases (no admitted patients) in hospitals and in other settings. The results from the pilot data collection confirmed that many countries are still only able to report data on day cases in hospital, while unable to report data on outpatient cases. But among those countries that are able to report the data on outpatient cases, the collection of these data are crucial to properly document the development of day operations. The pilot data collection also helped to clarify the definition of "day cases" in the regular data submissions, and that some countries were already including such outpatient cases under their reporting of day cases. Recognizing both the current limitations in the ability of many countries to report data on outpatient cases and 
the value of collecting these data in a clearly-defined way where possible, the OECD, Eurostat and WHO-Europe have agreed to collect data on outpatient cases for two surgical procedures (e.g., cataract surgery and tonsillectomy) that are performed to a large extent as day surgery in their joint questionnaire on non-monetary health care statistics in 2013.

Table 1

Total surgical procedures: comparison between OECD, Eurostat and WHO-Europe data

\begin{tabular}{|c|c|c|c|c|c|c|c|c|c|c|c|c|}
\hline & & \multicolumn{7}{|c|}{ Total number surgical procedures } & \multicolumn{4}{|c|}{ Difference in \% } \\
\hline & & \multicolumn{3}{|c|}{ OECD } & \multicolumn{3}{|c|}{ Eurostat } & \multirow{2}{*}{$\begin{array}{c}\text { WHO } \\
\begin{array}{c}\text { In- } \\
\text { Patient }\end{array}\end{array}$} & \multicolumn{2}{|c|}{ OECD/Eurostat } & \multirow{2}{*}{$\begin{array}{c}\text { OECD/ } \\
\text { WHO } \\
\begin{array}{c}\text { In- } \\
\text { Patient }\end{array}\end{array}$} & \multirow{2}{*}{$\begin{array}{c}\begin{array}{c}\text { WHOI } \\
\text { Eurostat }\end{array} \\
\begin{array}{c}\text { Day } \\
\text { case }\end{array} \\
\end{array}$} \\
\hline & & $\begin{array}{c}\text { In- } \\
\text { Patient }\end{array}$ & $\begin{array}{l}\text { Day } \\
\text { case }\end{array}$ & Total & In-Patient & $\begin{array}{l}\text { Day } \\
\text { case }\end{array}$ & Total & & $\begin{array}{c}\text { In- } \\
\text { Patient }\end{array}$ & $\begin{array}{l}\text { Day } \\
\text { case }\end{array}$ & & \\
\hline Austria & 2008 & & & $1,163,465$ & $4,549,073$ & & & $1,163,465$ & & & & \\
\hline Belgium & 2007 & 651,744 & 543,428 & $1,195,172$ & $6,244,114$ & $2,074,425$ & $8,318,539$ & 921,881 & $-90 \%$ & $-74 \%$ & $-29 \%$ & $-85 \%$ \\
\hline Czech Rep. & 2007 & 669,545 & & & & & & 861,531 & & & $-22 \%$ & \\
\hline Denmark & 2007 & 415,040 & 404,694 & 819,734 & 531,164 & 740,887 & $1,272,051$ & 531,146 & $-22 \%$ & $-45 \%$ & $-22 \%$ & $0 \%$ \\
\hline Estonia & 2008 & 87,998 & 44,663 & 131,661 & 399,889 & 46,257 & 446,146 & 87,998 & $-78 \%$ & $-3 \%$ & $0 \%$ & $-78 \%$ \\
\hline Finland & 2008 & 335,236 & 215,608 & 550,884 & 550,884 & 184,976 & 735,820 & 550,764 & $-39 \%$ & $17 \%$ & $-39 \%$ & $0 \%$ \\
\hline France & $\ldots$ & 0 & & & & & & & & & & \\
\hline Germany & 2008 & $5,424,693$ & $1,808,747$ & $7,234,440$ & $41,348,869$ & 443,961 & $41,792,830$ & $5,425,693$ & $-87 \%$ & $307 \%$ & $0 \%$ & $-87 \%$ \\
\hline Greece & 2006 & 731,900 & & & & & & 731,900 & & & $0 \%$ & \\
\hline Hungary & 2008 & 729,915 & 88,353 & 818,268 & & & & $1,256,126$ & & & $-42 \%$ & \\
\hline Iceland & 2007 & & & & & & & 11,248 & & & & \\
\hline Ireland & 2008 & 143,453 & 98,819 & 242,272 & $1,046,492$ & 966,482 & $2,012,974$ & 143,453 & $-86 \%$ & $-90 \%$ & $0 \%$ & $-86 \%$ \\
\hline Israel & 2008 & 359,747 & 143,920 & 503,666 & & & & 473,801 & & & $-24 \%$ & \\
\hline Italy & 2007 & $2,979,280$ & $1,610,009$ & $4,589,289$ & $6,161,460$ & $3,062,621$ & $9,225,081$ & $2,966,309$ & $-52 \%$ & $-47 \%$ & $0 \%$ & $-52 \%$ \\
\hline Luxembourg & 2007 & 57,096 & 38,497 & 95,593 & & & & & & & & \\
\hline Netherlands & 2007 & 651,335 & 664,031 & $1,315,366$ & 865,000 & $1,097,000$ & $1,962,000$ & 651,000 & $-25 \%$ & $-39 \%$ & $0 \%$ & $-25 \%$ \\
\hline Norway & $\ldots$ & & & & & & & & & & & \\
\hline Poland & 2007 & $4,455,277$ & 805,351 & $5,260,628$ & $16,029,769$ & $1,821,290$ & $17,851,059$ & & $-72 \%$ & $-56 \%$ & & \\
\hline Portugal & 2007 & 621,528 & 188,427 & 809,955 & & & & 809,956 & & & $-23 \%$ & \\
\hline Slovak Rep. & 2008 & & & & & & & 26,675 & & & & \\
\hline Slovenia & 2008 & 86,185 & 18,275 & 104,461 & & & & 159,697 & & & $-46 \%$ & \\
\hline Spain & 2008 & $2,262,880$ & $1,259,261$ & $3,522,141$ & $10,523,990$ & $2,860,008$ & $13,383,998$ & $2,262,880$ & $-78 \%$ & $-56 \%$ & $0 \%$ & $-78 \%$ \\
\hline Sweden & 2007 & 671,461 & & & 428,534 & $1,085,769$ & $1,514,303$ & 632,922 & $57 \%$ & & $6 \%$ & $48 \%$ \\
\hline Switzerland & 2007 & 962,136 & 174,507 & $1,136,643$ & 460,476 & 174,085 & $1,134,561$ & 514,864 & $0 \%$ & $0 \%$ & $87 \%$ & $-46 \%$ \\
\hline Turkey & 2008 & $6,081,471$ & & & & & & $6,081,471$ & & & $0 \%$ & \\
\hline UK & 2007 & $4,406,428$ & $5,248,580$ & $9,655,008$ & $4,029,923$ & $5,734,170$ & $9,761,093$ & $4,978,511$ & $9 \%$ & $-8 \%$ & $-11 \%$ & $24 \%$ \\
\hline
\end{tabular}

Source: OECD Health Data 2010; WHO-Europe HFA; Eurostat data.

It is one of the reasons why we decided to search for the barriers of collecting data about day surgery in Slovakia and to propose activities, which would allow other countries to get involved in a joint data collecting and comparison scheme. 
Until 2010 the OECD and Eurostat realized data collecting about surgical performances using two types of reports: report with aggregated data with total number of performances, as well as report with detailed data regarding selected performances. WHO-Europe focused data collecting overall numbers regarding two data groups:

a) File of aggregated data - all types of surgical performances in the group of in-patient and day cases,

b) File of structured data - gained on the base of surgery performance classification. The classification criteria is high number, or eventually high costs, with respect to in-patient and day cases where applicable (relevant).

Figure 2

Disparities in definition of surgical data for performance evaluation

WHO-Europe definition:

Summary of all surgical performances types (invasive) provided as:

\section{In-patient cases}

Only main surgical procedure can be reported, applied to patient during hospital stay.
Invasive therapies provided by the form of hospital surgery, where the hospital surgery is defined as surgery or procedure linked with overnight stay of the patient in hospital.
Differences in

\section{OECD definition:}

Summary of all surgical performances (invasive) provided as in-patient cases and day surgeries. Only main surgical procedure can be reported, applied to patient during hospital stay.

\section{Eurostat definition:}

The performance represents all types of medical procedures with the focus on achievement of the medical results in the care for people with health problems.

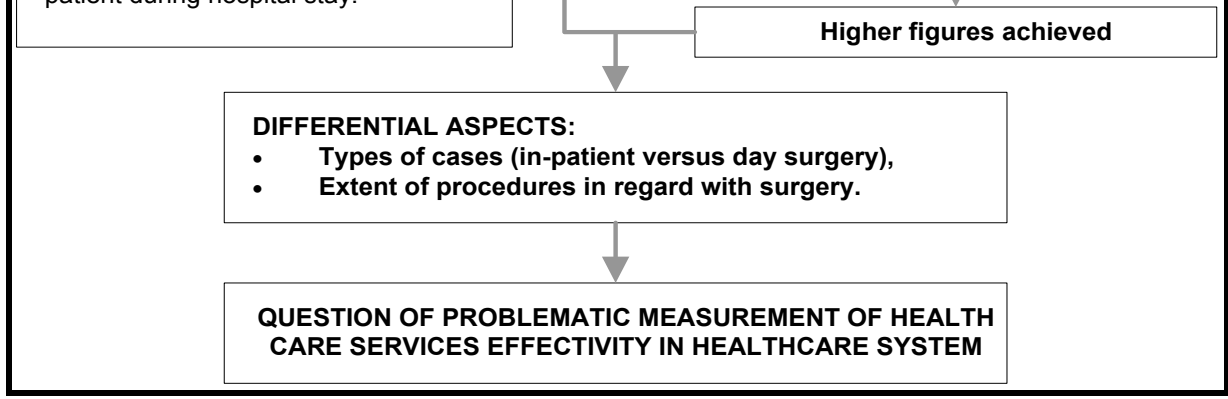

Source: Authors based on WHO, Eurostat and OECD definitions. 
The performance data comparison from international organizations (OECD, Eurostat and WHO) shows disparities. The problem is in contradicting definition used in data collecting process (Figure 2). The disparities cause problems with reporting of consistent and comparative data. Definition according to Eurostat has more general, wider character then stated definition according to OECD and WHO-Europe. It is from the reason of implementation other performances, as stated in definition. This fact is significantly consequential for reporting many more number of performances reported in data from Eurostat, in comparison with reported data for OECD or WHO-Europe (with respect to exception).

In continuity with above mentioned, international organizations agreed on discontinuation of collecting data about the overall number of surgical procedures until the time, when international classification of procedures with be agreed and implemented. This classification would guarantee higher consistency of reported data between the countries. Those conclusion fully correspond with the conclusions of the Hospital Data Project 2 (EC, 2008), that also appealed from the same reason on discontinuation of collecting data about the number of surgical procedures (EC, 2008).

\section{RESEARCH STUDY - DAY SURGERY USE IN SLOVAKIA}

Day surgery use is highly effective tool for health care services providing, but it is applied in unsustainable conditions of the Slovak healthcare. It is a suitable theme for polemics of various subjects of healthcare system, as well as the professional and general public environment. International studies declare numerous researches in stated area, supporting continuous improvement of the day surgery system, functioning for the more than 30 years. Day surgery system in Slovakia has not got sufficient financial support from the side of health care insurance companies, which wider the number of surgeries types without mapping the conditions for its suitability. For the last fifteen years of day surgery existence in Slovakia were not provided any researches declaring the state, as well as the potential possibilities for development. It is not mapped the risk of the selected types of performances for various age patient groups, the increase of the costs for the repeated return of the patient after day surgery, total benefits of the day surgery use.

The own research is realized on the basis of meetings with the selected actors of day surgery in Slovakia, as well as by analysis of data gained from healthcare providers. The base for analysis of day surgery in Slovakia was report provided by the Ministry of Economy in Slovakia about Day surgery for the years 2009 - 2011. The structure of the report is shown on Table 2. 


\section{Table 2}

Day surgery Annual Report of the Ministry of Economy in Slovakia

\begin{tabular}{|c|c|c|c|c|c|}
\hline \multirow{2}{*}{$\begin{array}{c}\text { Day surgery } \\
\text { performance }\end{array}$} & \multirow{2}{*}{$\begin{array}{c}\text { Performance } \\
\text { code }\end{array}$} & \multicolumn{3}{|c|}{ Number of patients 1) } \\
\cline { 3 - 6 } & & $0-18$ & $19+$ & $0-18$ & hospitalized after the surgery \\
\cline { 3 - 6 } & & 1 & 2 & 3 & 4 \\
\hline Performance & $\mathrm{a}$ & 1 & \multicolumn{4}{|c|}{ operated } \\
\hline
\end{tabular}

Source: National Health Information Center (NHIC).

This report indicates the number of patients according to the type of code that stands for a particular type of medical surgery. Following the practice of data aggregation stated by the National Health Information Center (NHIC), it was not possible to obtain the data from the years before 2009. The data were structured in a form which contains the frequency of performances for the reporting period (year), regions and then aggregated.

\section{Main actors of research}

The actors of research who participated in the research study directly or indirectly and affect the system of day surgery in Slovakia are:

- health care providers,

- Slovak Association of Day Surgery (SADS),

- Association of Hospitals in Slovakia (AHS),

- health insurance companies in Slovakia - Dôvera, Union, VšZP (General health insurance company),

- Healthcare Surveillance Authority (HSA),

- Ministry of Health in Slovak republic (MH SR),

- National Health Information Center (NHIC).

\section{Research study information sources}

The study is based on primary and secondary sources of information. Important sources of information were electronic databases available on the Internet, such as Web of Knowledge, Research Papers of Economics, EBSCO HOST Research Databases etc. The knowledge gained from background research and by selecting of scientific and professional resources was systematized on theoretical basis and at the same time as information platform for the research part of this research study. These materials were the first group of secondary data. The second group of the secondary data consisted of the material obtained from personal and written communication with health care providers, SADS, NHIC, 
all three health insurance companies in Slovakia (Dôvera, Union and V̌̌ZP), as well as the data from the Annual Statement Report about day surgery for 2009 2011 years.

\section{Research methods}

The obtained data from primary research were processed using managerial and statistical methods. To process obtained data, we used general theoretical methods (abstraction, analysis, synthesis, induction, deduction and comparison), as well as special managerial method (SWOT analysis) and statistical methods (descriptive statistical methods).

Figure 3

Basic scenario of SWOT analysis for day surgery

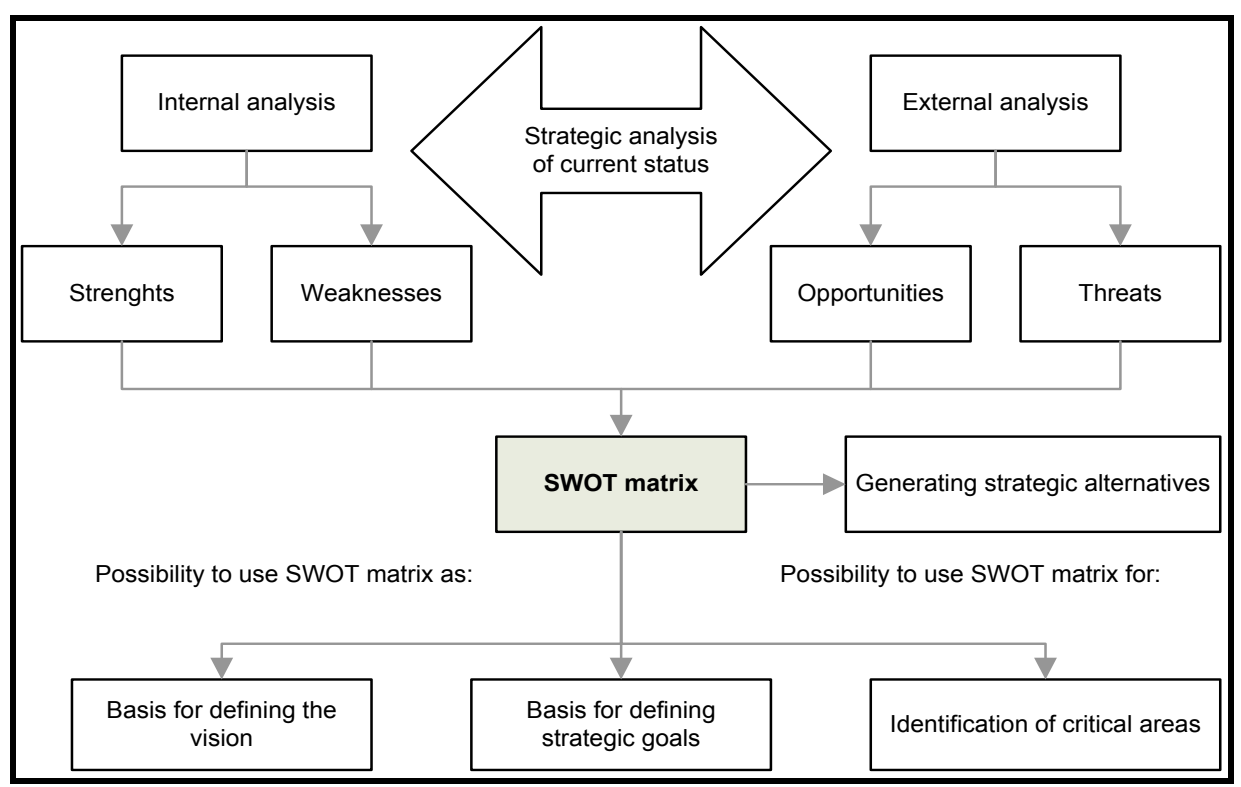

Source: Processed according to Grasseová et al., (2010).

The special multilevel SWOT analysis was used as analytical method of strategy analysis. SWOT analysis was selected based on the McSherry and Warr (2008) research studies, who recommend this method as one of the method and tools in the process of day surgery development. For SWOT analysis construction was necessary to implement the expert group method, as well as unstructured interview with selected day surgery actors for obtaining primary research data. For the overall evaluation of functionality of day surgery system we use the comparison of each basic factor of SWOT analysis: strengths, weaknesses, 
opportunities and threats. Selection of SWOT analysis elements was realized through expert evaluation associated with Brainstorming. At the beginning of the process the expert identified the strengths, weaknesses, opportunities and threats. They did not evaluate each element among themselves. We obtained the list of SWOT analysis components (strengths and weaknesses, opportunities and threats) with the equal weight.

The basic strategies can be expressed in the form of matrix which is shown on Figure 3.

The construction of multilevel SWOT analysis requires understanding of methodology as follows.

Suppose we have $m$ experts to determine $n$ strengths. Therefore, after the identification of strengths in the second step of the evaluation is necessary to provide their mutual evaluation. This evaluation is carried out through expert evaluation method using pairwise comparisons, based on the assumption of mutual pairwise evaluation of all those pairs of alternatives. This creates a problem for large samples, where there is a need for total $\frac{n}{2}(n-1)$ pairs (evaluations). On this basis, we define the following table that will be completed by reviewers (experts) (Table 3 ).

Table 3

Pairwise comparison

\begin{tabular}{|c|c|c|c|c|c|c|}
\hline & A & B & C & D &.. & Priority $\left(\right.$ PRS $\left._{i j}\right)$ \\
\hline A & & A & C & A &.. & 2 \\
\hline B & & & B & D &.. & 1 \\
\hline C & & & & C &.. & 1 \\
\hline D & & & & &.. & 1 \\
\hline$\ldots$ & & & & & & \\
\hline
\end{tabular}

Source: Own elaboration.

The table will have variables in columns and rows, and their mutual comparison of each evaluator states the alternative that has the higher priority. Accordingly, each evaluator identifies the frequency of priority of that alternative to other alternatives.

Based on these values for each alternative we calculate the absolute value of priority. We mark it as $P V S_{i}$, where $i$ represents the sequence number of alternative. This can be calculated as follows:

$$
P V S_{i}=\sum_{j=1}^{m} P R S_{i j}
$$


where $i=\{1,2, \ldots n\}$ and a $j=\{1,2, \ldots m\}$

Then we assess the weight of each alternative through standardization using the following formula.

$$
v p s_{i}=\frac{P V S_{i}}{\sum_{i=1}^{n} P V S_{i}}
$$

where $i=\{1,2, \ldots n\}$

On the basis of above we computed set of alternatives weights whose sum is equal to one.

$$
\sum_{i=1}^{n} v p s_{i}=1
$$

where $i=\{1,2, \ldots n\}$

The subsequent score of each of the strengths is achieved through 1-7 point scale, where 1 represents the lowest and 7 is the highest level. The values are then multiplied by the rate scales. The value of strengths can be calculated:

$$
\bar{s}_{i}=\frac{\sum_{j=1}^{m} s_{i j}}{m}
$$

where $i=\{1,2, \ldots n\}$ and $j=\{1,2, \ldots m\}$.

In a similar way, we can calculate an overall assessment of the weaknesses. In the next chapter 4 we summarize the results and suggestions for the policymakers and healthcare systems, and further development of day surgery. Chapter 5 brings the discussion about the barriers, implications and recommendation.

\section{RESULTS}

Day surgery is highly effective tool for providing health care, but it is applied in non-stabile conditions of Slovak healthcare. It is a suitable theme for discussion of various representatives of healthcare system, as well as specialized and general public. Information also absent on the side of each health care insurance company. Problems could be found in the primary data collection, where in reporting of each surgical performance frequencies on the base of professional guidance of the Ministry of Health find out many irregularities and their incompatibility. International studies declare many researches in specified area, supporting continuous improvement of day surgery system, which is functional more than thirty years. Day surgery system in Slovakia has 
not enough financial support from the side of health insurance companies, which spread the number of performances without mapping the conditions and its relevance. For fifteen years of day surgery existence in Slovakia, no researchers declared the status and potential possibilities of development. The risk of selected types of performances is not mapped for various age groups, the increase of costs for treatment in case of repeated return of patient after day surgery performance, total benefits from using day surgery compared to hospitalization performance for given type of diagnosis (cost saving of health care insurance company), including early return of patient to working environment (insurance fees to health care insurance company). The above mentioned have prompted us to realization of the first pilot research focused on implementation and use of day surgery in Slovakia, whose results will help to the creators of healthcare politics for drafting of strategic goals of healthcare system in Slovakia (Gavurová et al., 2013). The basic goal of the research is to evaluate the functioning of the current day surgery in Slovakia, identify its important determinants and specify its critical areas. On the base of research results we propose the possibilities of its further development.

The evaluation process is presented in Table 4.

Table 4

Level of day surgery functionality - results from SWOT analysis

\begin{tabular}{|c|c|c|c|}
\hline & $\begin{array}{l}\text { Functionality level of } \\
\text { day surgery system }\end{array}$ & $\begin{array}{l}\text { Significant shortcomings } \\
\text { in day surgery system }\end{array}$ & Outcomes from SWOT analysis \\
\hline 1. & $\begin{array}{l}\text { Fully functional to very } \\
\text { well-functioning system } \\
\text { of day. }\end{array}$ & $x$ & $\begin{array}{l}\text { Prevalence of strengths over the } \\
\text { weaknesses. Prevalence of } \\
\text { opportunities over the threats. }\end{array}$ \\
\hline 2. & $\begin{array}{l}\text { Functional day surgery } \\
\text { system. }\end{array}$ & $\begin{array}{l}\text { Incorrect setting of day surgery } \\
\text { components setting. }\end{array}$ & $\begin{array}{l}\text { Prevalence of weaknesses over the } \\
\text { strengths. } \\
\text { Prevalence of opportunities over the } \\
\text { threats. }\end{array}$ \\
\hline 3. & $\begin{array}{l}\text { Day surgery system with } \\
\text { limited functionality. }\end{array}$ & $\begin{array}{l}\text { Absenting components in day } \\
\text { surgery system. }\end{array}$ & $\begin{array}{l}\text { Prevalence of strengths over the } \\
\text { weaknesses. } \\
\text { Prevalence of threats over the } \\
\text { opportunities, while the time of threat } \\
\text { is } 40 \% \text { from planning time. }\end{array}$ \\
\hline 4. & $\begin{array}{l}\text { Mainly non-functional } \\
\text { day surgery system }\end{array}$ & $\begin{array}{l}\text { Absenting components and } \\
\text { wrong setting of existing day } \\
\text { surgery system components }\end{array}$ & $\begin{array}{l}\text { Prevalence of weaknesses over the } \\
\text { strengths. } \\
\text { Prevalence of threats over the } \\
\text { opportunities, while the time of threat } \\
\text { time is up to } 40 \% \text { from planning time. }\end{array}$ \\
\hline 5. & $\begin{array}{l}\text { Fully dysfunctional day } \\
\text { surgery system }\end{array}$ & $\begin{array}{l}\text { Absenting conditions necessary } \\
\text { to implement and use of day } \\
\text { surgery system. }\end{array}$ & $\begin{array}{l}\text { Prevalence of weaknesses over the } \\
\text { strengths. } \\
\text { Prevalence of threats over the } \\
\text { opportunities, while the time of threats } \\
\text { continuance is over the } 40 \% \text { from } \\
\text { planning time. }\end{array}$ \\
\hline
\end{tabular}

Source: Own elaboration. 
On the base of stated evaluation, we can consider day surgery system in Slovakia as functional, but single components of the system are incorrectly set, as opportunities prevail over threats, but weaknesses prevail over strengths of that system. From the research results, we selected the partial conclusion. Each part of the results contains concrete suggestions made upon our research results.

\section{Evaluation of the use of day surgery in Slovakia}

- Absence or insufficient quantification of day surgery benefits in terms of health insurance companies, health care providers, associations, etc.

- Insufficient information for potential patients about the benefits, safety, risks and availability of day surgery, from both health insurance companies (lack of information from the web sites), by general practitioners, SADS (focused exclusively on the activities of the association, not on the improvement of potential patients' awareness).

- The absence of any research studies from academic field as well as from medical institutions focusing on content, respectively procedural aspect of the day surgery implementation, which analyzes patient satisfaction at a given day surgery, its availability, risk level based on age, sex, comorbidities, degree of obesity, etc.

\section{Suggestions for the policymakers and healthcare systems and further development of day surgery}

- Unbalanced view on day surgery as a whole unit.

- The risk of focusing attention only on the aspect of significant savings of health insurance companies' resources without complementary analysis of affordability and suitability of day surgery for selected types of patients, as well as taking into account the social aspects of day surgery efficiency.

- Reducing the importance of day surgery under its uselessness or non-importance.

- Increased resistance of health care providers to accept changes caused by the use and expansion of day surgery.

- The absence of distinct connection of pursued development objectives and day surgery effectiveness with the strategy of hospitals.

\section{DISCUSSION}

Day surgery present the innovative approach to the surgical health care, therefor it requires the support for change (Jarrett - Staniszewski, 2006). The 
first impulse to change the prevalence opinion about day surgery development support was a pilot study conducted in France by National insurance company about the experiences with day surgery (Toftgaard and Parmentier, 2006). As the basic barriers preventing to effective development of day surgery could be stated regulative, economical, educational and organizational barriers.

As shown on Table 5, there are also barriers in informing patients, in configurations of the current and new kinds of surgical operations, problems with local, domestic and public support, etc.

Table 5

The basic barriers of day surgery development

\begin{tabular}{|l|l|}
\hline \multicolumn{1}{|c|}{ EXTERNAL BARRIERS } & \multicolumn{1}{c|}{ INTERNAL BARRIERS } \\
\hline $\begin{array}{l}\text { Regulative barriers - national directions and } \\
\text { legislative regulations. }\end{array}$ & $\begin{array}{l}\text { Incompatibility of available health care providers as } \\
\text { a barrier to day surgery development. }\end{array}$ \\
\hline $\begin{array}{l}\text { Insufficient domestic, regional and public support. } \\
\begin{array}{l}\text { The absence of adequate social services which are } \\
\text { the barrier to undergoing day surgery. }\end{array}\end{array}$ & $\begin{array}{l}\text { Education - lack of day surgery educational } \\
\text { programs for students of 2nd and 3rd level of higher } \\
\text { education. }\end{array}$ \\
\hline $\begin{array}{l}\text { Economic barriers - in case of advantageous } \\
\text { hospitalization to day surgery for hospitals. Or if } \\
\text { patient cover part of costs for day surgery, while } \\
\text { during hospitalization it is not needed. }\end{array}$ & $\begin{array}{l}\text { Public awareness - the absence of information on } \\
\text { opportunities of day surgery. }\end{array}$ \\
& $\begin{array}{l}\text { Organizational barriers - weak multidisciplinary } \\
\text { collective team work. }\end{array}$ \\
\hline
\end{tabular}

Source: Own elaboration.

In results we evaluate day surgery benefits in Slovakia in verbal. The reason is that health care facilities do not realize quantification of benefits from using day surgery in the form of concrete values; we did not gain any information about realization of return analysis. Means there are no analysis realized for evaluation of finance return for using day surgery. Therefore we consider our research and proposal of alternatives evaluating benefits from implementing as another suitable proposal for the following researches.

Based on the research results, we noted significant shortcomings in the implementation and use of day surgery in Slovakia. Therefore, in subsequent studies we recommend a deeper analysis of the essential criteria of day surgery, ex. application of methods for determining the scales between criteria. As a criterion in the context of day surgery we indicate those components of the day surgery system whose significance we want to find by calculation of scales. The scales should be redefined and reviewed in those parts of the system, which are directly derived from the strategy of health care facility (e.g. strategic principles, perspectives, objectives, benchmarks and their values, strategic initiatives, etc.).

For this reason, we recommend the application of Analytic Hierarchy Process (AHP) method, which is a flexible model for decision-making and allows 
clarifying problems that have several possible solutions. This method is carried out firstly by the expert method and subsequently by mathematical method. Important principles of AHP method are hierarchy, priorities and consistency. Analysis of day surgery provides a valuable starting point also for realization of strategic benchmarking. Day surgery has fundamental principles which are based on comparative aspects of the implementation of performances through day surgery and by the hospitalization form. Therefore, as a topic for further research we recommend its application by AHP for comparison of the principles of day surgery functionality of selected health care facilities. Day surgery has fundamental principles which are based on comparative aspects of the implementation of performances through day surgery and by the hospitalization form (the traditional way). Those principles will represent the evaluation criteria, the expert group will provide a set of sub-criteria for each criteria as a basis for comparison - benchmarking of health care providers using day surgery (detailed procedure in the publication of Gavurová, 2012). In the professional literature there are very few clinical studies based on comparisons of traditional inpatient surgery and day surgery.

Patient satisfaction is another very general relative measure of the health care quality, affected by various factors, such as overall expectations of the patient, age of the patient, his disease, previous positive experience, choice of health care provider, professional relationship between patient and doctor, gender, ethnicity, socio - economic status. The relevant professional literature does not provide any unified questionnaires, which would be recommended in the process of evaluation of patient satisfaction with day surgery (Klepáková, 2013). In the frame of availability, efficiency, risk and suitability (in terms of selected types of patients) realization of day surgery would be appropriate to capture the demographic and social aspects of individual regions of Slovakia due to the existence of regional disparities. An insufficient information about day surgery causes that patients are worried about the long-term hospital stay for conventional surgery. This leads to neglecting health status and possible health complications, sometimes with the tragic consequences. Underdeveloped regions have considerably reduced transport possibilities, which make a barrier to health services access and in case of day surgery one of the barriers of its development. Social aspects should be mentioned also in the context of living standard of citizens, where are notable difference in various regions of Slovakia (taking account on Roma community). Day surgery development also requires an effective postoperative care, respectively home care, availability of relatives or friends who provide to the patient post-operative care with the availability of communication medium. In our analysis, when evaluating the benefits of using day surgery in Slovakia, we verbally assess benefits from the use of day surgery. Medical facilities do not quantify the benefits from the day surgery in terms of value indicators. We did not obtain any information about the analysis 
of returns or funds spent on implementation and use of day surgery. We therefore consider a proposal of benefits gained by introduction and extension of the use of day surgery as another suitable proposal for next researches.

The following Figure 4 summarizes all aspects of day surgery in Slovakia that need to be taken into consideration for its future development.

Figure 4

Day surgery implications in the context of healthcare system

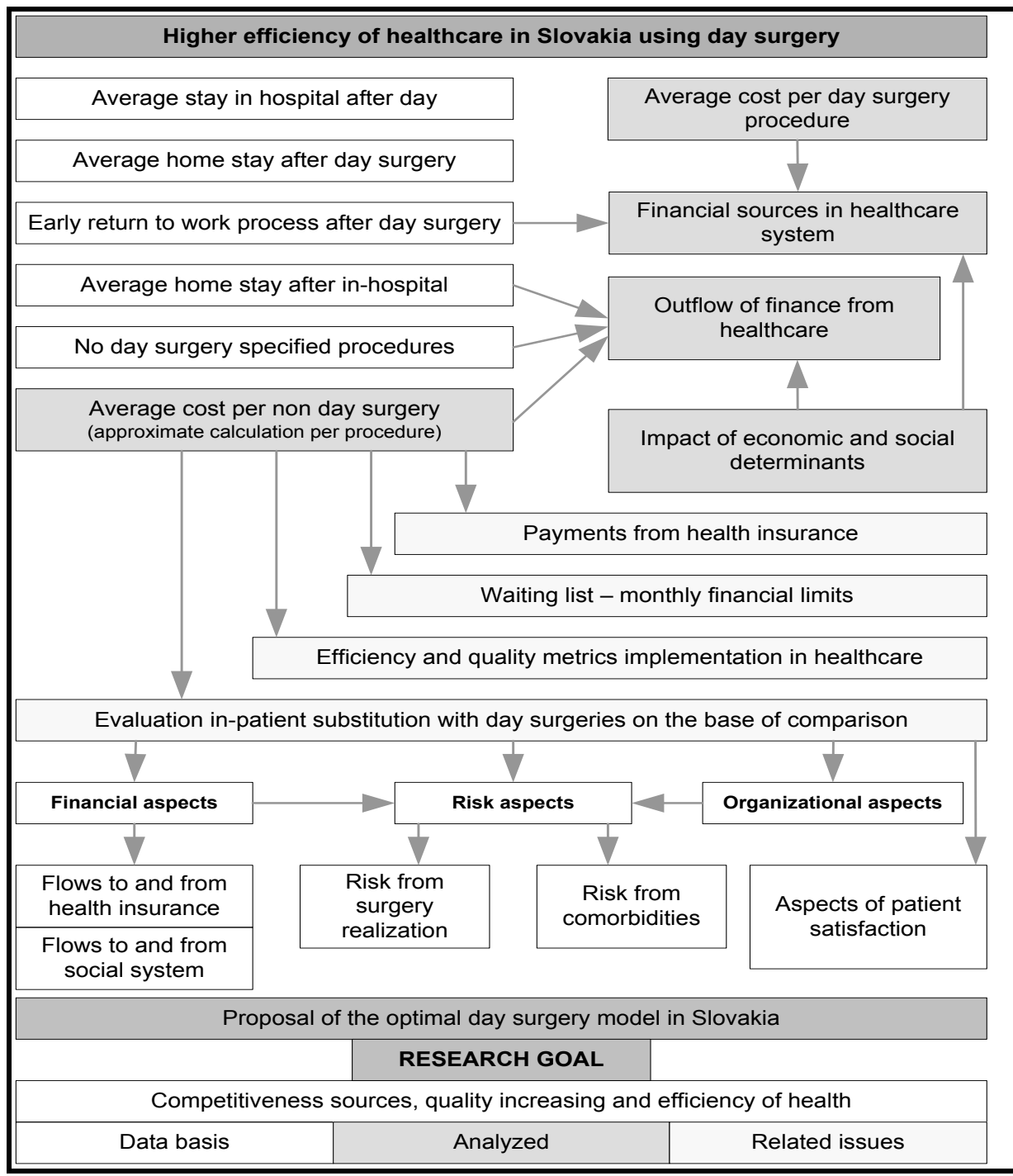

Source: Own elaboration. 
Social aspects should be mentioned also in the context of living standard of citizens, where are notable difference in various regions of Slovakia. Day surgery development also requires an effective postoperative care, respectively home care, availability of relatives or friends who provide to the patient postoperative care with the availability of communication medium. In our analysis, when evaluating the benefits of using day surgery in Slovakia, we verbally assess benefits from the use of day surgery. Medical facilities do not quantify the benefits from the day surgery in terms of value indicators. We did not obtain any information about the analysis of returns or funds spent on implementation and use of day surgery. We therefore consider a proposal of benefits gained by introduction and expansion of the use of day surgery as another suitable proposal for next researches.

\section{CONCLUSION}

The primary objective of the conducted research is to evaluate the day surgery system functionality in Slovakia. Through an application of a multilevel SWOT analysis the day surgery system was identified as functional. However its components are not correctly set. It is also caused by insufficient engagement of stakeholders and profaneness of declared day surgery outputs only within financial savings of health insurance companies. The results of this scientific work may contribute to prediction and elimination of undesired effects in the day surgery system of examined medical institutions and for day surgery players to contribute to its further development in Slovakia.

Further development of day surgery in upcoming years is connected to various factors. The most important one is financial influence depending on the approach of health insurance companies to the day surgery system, its main actors and government support. Health insurance companies should reduce the limits on the number of day surgery operations and set a unit price for an operation at least on the level of an inpatient surgery. Moreover, the situation will also depend on the further development of surgery methods and anesthetic care and their impact on less aggressive surgery and postoperative complications and mortality. Another important factor is a social factor which affects the length of hospital stay after surgery and the choice of day surgery operation. Moreover, the satisfaction of a patient with the conducted day surgery operations, the doctor and medical personnel with conditions for the day surgery operations and possibilities and means of an effective communication of the personnel with patients was and will be important, too. Experts on this issue remain skeptic in the issues of further day surgery development. The reason is persistent problems related to health insurance reimbursements for surgical procedures as well as their monthly financial limits, causing the creation of waiting lists in the day surgery facilities. 
It is also necessary to set such a health care system, in which simple procedures will be connected to lower payments and more complex operations to higher prices. Otherwise there can be no radical changes in the day surgery progression. If hospitals are paid fairly for complex operations, they might be willing to reduce the simpler ones and to create one-day surgery centers. Whether further development of the day surgery in Slovakia changes, accelerates and becomes more efficient to the level of other developed countries, the future will show. In the presented outcomes we would like to draw an attention to the issues related to reporting data. The Slovak National Health Information Center plans to adjust data reporting structure to the European standards in 2015. Therefore, the output of our research will be the proposal for the changes in current reporting, with the goal to implement the standard parameters of different types of health care according to developed countries. Subsequently it will be possible to provide performance and strategic benchmarking. Many of our previous analyzes were limited by improper data reporting. Hence, our recommendations are based, except the results of our own research, from the multiple foreign research studies where the platform of highquality data sources already works. Achievement of this change in data reporting would bring an opportunity for wide margin for multi variants economic and medical analysis. The research outcomes would be beneficial for the development process in hospitals and more efficient for healthcare system. This enables the adjustment of overall parameters and benchmarking of performance, efficiency and quality of health care.

\section{REFERENCES}

AYLIN, P.; WILLIAMS, S.; JARMAN, B.; BOTTLE, A. (2005): "Trends in day surgery rates" in BMJ, Vol: 331(7520): 803.

BEAUREGARD, L.; POMP, A.; CHOINIÉRE, M. (1998): "Severity and impact of pain after day-surgery" in Can J Anaesth, Vol: 45, pp. 304-311.

EC (2008), Hospital Data Project Phase 2, Final Report: The equal need for metadata and data, European Commission, Luxembourg, November 2008.

GAVUROVÁ, B.; ŠOLTÉS, V.; KAFKOVÁ, K., et al., (2013): Selected aspects of Slovak healthcare effectivity. Day surgary and its development in conditions of SR, Košice: Technická univerzita v Košiciach.

GRASSEOVÁ, M.; DUBEC, R.; ŘEHÁK, D. (2010). Analýza v rukou manažera. Brno: Computer Press, 2010, pp. 325.

HUDECOVÁ, D. (2010): "Interest of day surgery is growing. Where is it convenient?" Available at: http://zdravie.pravda.sk/zdravie-a-prevencia/ 
clanok/12966-zaujem-o-jednodnovu-chirurgiu-rastie-kde-je-vyhodna/ [16.06.2013].

Internal materials of organizations: Slovak Association of day surgery, 2012; Healthcare Surveillance Authority, 2012, health insurance companies Dôvera, Union, VšZP (General health insurance company).

JARRETT, P. E. M. - ROBERTS, L. M. 2006. Planning and designing a Day Surgery Unit. In: Lemos $P$, Jarrett $P$, Philip B, eds. Day Surgery Development and Practice. London, UK: International Association for Ambulatory Surgery (IAAS) 2006: 61-87.

KLEPÁKOVÁ, A. (2013): "Aspects of unified methodology for patient satisfaction evaluation for hospitalized patients" in Forum statisticum Slovacum, Vol: 9 (4), pp. 136-141.

KLEPÁKOVÁ, A. - GAVUROVÁ, B. 2012. Kritické aspekty komunikácie medzi verejnými zdravotnými poist'ovňami a poskytovatel'mi zdravotných služieb na Slovensku. In: Manažment podnikania a vecí verejných: zborník vedeckých prác. Bratislava: Slovenská akadémia manažmentu, 2012, roč. 2, č. 2, s. 317-323. ISBN 978-80-970759-2-7

KOECHLIN, F.; LORENZONI, L.; SCHREYER, P. (2010): "Comparing Price Levels of Hospital Services across Countries: Results of a Pilot Study", OECD Health Working Paper, No. 53, OECD Publishing, Paris.

LAFORTUNE, G., BALESTAT, G.; DURAND, A. (2012): OECD Health Division Comparing activities and performance of the hospital sector in Europe: how many surgical procedures performed as inpatient and day cases? Directorate for Employment, Labour and Social Affairs. Health Policy, Volume 68, Issue 2, May 2004, Pages 183-196, "Day surgery and hospital efficiency: empirical analysis of Norwegian hospitals, 1999-2001" by Pål E.Martinussen and Linda Midttun".

MARTINUSSEN, P. E.; MIDTTUN, L. (2004): "Day surgery and hospital efficiency: empirical analysis of Norwegian hospitals 1999-2001", in Health Policy, Vol. 68 (2), pp. 183-196.

MARTINUSSEN, P. E.; HAGEN T. P. (2009): "Reimbursement systems, organisational forms and patient selection: Evidence from day surgery in Norway", in Health Economics, Policy and Law, Vol. 4 (02), pp 139-158.

McSHERRY, R. - WARR, J. 2008. An Introduction to Excellence in Practice Development in Health and Social Care. Open University Press, McGraw Hill Education, Berkshire.

OECD and EC (2012), Health at a Glance: Europe 2012, OECD Publishing, DOI : http://dx.doi.org/10.1787/9789264183896-en

OECD documents. http://search.oecd.org/officialdocuments/ displaydocumentpdf/ ?cote $=$ delsa/hea/wd/hwp(2010)4\&doclanguage $=e n$

SMITH, I. - COOKE, T. - JACKSON, I. - FITZPATRICK, R. 2006. Rising to the challenges of achieving day surgery targets. In: Anaesthesia 2006; 61: 11919. 
TOFTGAARD, C. - PARMENTIER, G. 2006. International terminology in ambulatory surgery and its worldwide practice. In: Lemos $P$, Jarrett P, Philip B, eds. Day Surgery Development and Practice. London, UK: International Association for Ambulatory Surgery (IAAS) 2006: 35-59. 